\title{
Quality of life in persons living with HIV-AIDS in three healthcare institutions of Cali, Colombia
}

\author{
Claudia Patricia Valencia, MSc ${ }^{1}$, Gladys Eugenia Canaval, PhD ${ }^{1}$, Diana Marín² ${ }^{2}$, \\ Carmen J. Portillo, PhD $^{3}$
}

\section{SUMMARY}

Antecedents: The Human Immunodeficiency Virus is currently considered a chronic disease; hence, quality of life is an important goal for those suffering the disease or living with someone afflicted by the virus.

Objectives: We sought to measure the quality of life in individuals living with acquired immunodeficiency syndrome virus and establish its relationship with socio-demographic and clinical variables.

Methods: This is a cross-sectional, descriptive study with a sample of 137 HIV-infected individuals attending three healthcare institutions in the city of Cali, Colombia. Quality of life was measured via the HIV/AIDS-Targeted Quality of Life (HAT-QoL) instrument. The descriptive analyses included mean and standard deviation calculations. To determine the candidate variables, we used the student $t$ test and the Pearson correlation. The response variable in the multiple linear regression was the score for quality of life.

Results: Some $27 \%$ of the sample were women and $3 \%$ were transgender; the mean age of the sample was $35 \pm 10.2$ years; $88 \%$ had some type of health insurance; $27 \%$ had been diagnosed with AIDS, and 64\% were taking antiretroviral medications at the time of the study. Quality of life was measured through a standard scale with scores from 0 to 100 . Participants' global quality of life mean was $59 \pm 17.8$. The quality-of-life dimensions with the highest scores were sexual function, satisfaction with the healthcare provider, and satisfaction with life. The highest quality-of-life scores were obtained by participants who received antiretroviral therapy, had health insurance, lower symptoms of depression, low frequency and intensity of symptoms, and no prior reports of sexual abuse. Eight variables explained 53\% of the variability of the global quality of life.

Conclusions: Those receiving antiretroviral therapy and who report fewer symptoms best perceived their quality of life.

Implications for practice: Healthcare providers, especially nursing professional face a challenge in caring to alleviate symptoms and contribute to improving the quality of life of their patients.

Keywords: Quality of life; Symptoms,; HIV; AIDS; Health; Care; Nursing.

Calidad de vida en personas con VIH-SIDA en tres instituciones de salud de Cali, Colombia

\section{RESUMEN}

Antecedente: Hoy en día se considera el VIH como una enfermedad crónica; por tanto,la calidad de vida es una meta importante de alcanzar en las personas que viven y conviven con el virus.

Objetivos: Medir la calidad de vida en personas que viven con el virus del sida y establecer la relación con variables sociodemográficas y clínicas.

Métodos: Estudio transversal, descriptivo, con muestra no probabilística de 137 personas con VIH que asistieron a tres instituciones de salud de Cali, Colombia. La calidad de vida se midió con el instrumento Hiv/Aids-Targeted Quality of Life (HAT-QoL). El análisis descriptivo incluyó los cálculos de promedio y desviación estándar. Para determinar las variables candidatas se utilizaron la prueba t de Student y la correlación de Pearson. La variable respuesta en la regresión lineal múltiple fue el puntaje de calidad de vida.

1. Professor, Research Group on Health Promotion (PROMESA), School of Nursing, Universidad del Valle. Cali, Colombia. Member of the International Nursing and HIV -AIDS Research Network.e-mail: claudia.p.valencia@ correounivalle.edu.co glacanav@univalle.edu.co

2. Statistician, Hospital Epidemiology, Hospital Universitario del Valle, Cali, Colombia.e-mail: dmarin@ hotmail.com

3. Professor School of Nursing, University of California, Co-Director International Nursing and HIV -AIDS Research Network. e-mail: cportillo@ nursing.ucsf.edu

Received for publication November 4, 2008 Accepted for publication March 18, 2010 
Resultados: De los encuestados $27 \%$ eran mujeres y $3 \%$ transgéneros; la edad promedio fue $35 \pm 10.2$ años; $88 \%$ tenían algún tipo de seguro de salud; $27 \%$ con diagnóstico de Sida y $64 \%$ con tratamiento antirretroviral en el momento del estudio. La calidad de vida se midió con una escala estandarizada de 0 a 100; el promedio de calidad de vida global fue de $59 \pm 17.8$; las dimensiones de calidad de vida que mayor puntaje obtuvieron fueron la función sexual, la satisfacción con el proveedor de cuidados de salud y la satisfacción con la vida. Los puntajes más altos en calidad de vida los obtuvieron personas que recibieron tratamiento antirretroviral, con acceso a algún seguro de salud, menor sintomatología depresiva, baja frecuencia e intensidad de síntomas y sin antecedentes de abuso sexual. Ocho variables explicaron $53 \%$ de la variabilidad de la calidad de vida.

Conclusión: Las personas que reciben tratamiento antirretroviral y que informan menos síntomas son quienes mejor perciben su calidad de vida. Implicaciones para la práctica. Los proveedores de salud especialmente los profesionales de enfermería tienen un reto en el cuidado para aliviar los síntomas y hacer un aporte a la calidad de vida de los pacientes.

Palabras clave: Calidad de vida; Síntomas; VIH; Sida; Salud; Cuidado; Enfermería.

Herein, we introduce the results obtained on quality of life from the third study titled «Symptoms and selfcare in people with HIV-AIDS ${ }^{1-3}$ conducted in different nodes by the International Nursing and HIV-AIDS Research Network, led by the University of California. This article presents the results from the node in the city of Cali, Colombia.

The concept of health and its relationship with quality of life has been suggested by several authors from different approaches. Health has been traditionally seen as an aspect opposed to disease, even though the World Health Organization (WHO) redefined it over five decades ago as a state of complete wellbeing, still today health and its promotion are not emphasized by the programs of healthcare providers for individuals with some diagnosis of chronic disease like that related to Human Immunodeficiency Virus-Infected Individuals (PLWHA); this has led healthcare providers and researchers to make measurements of the health and wellbeing of individuals in very limited manner ${ }^{4}$.

Quality of life is a goal of health systems and of public health policies; quality of life is currently a measurement that indicates the lack of or presence of wellbeing, it is a measurement that is used as a positive indicator regarding individuals' relationship with health and it is used to measure the effects or its relationship with disease $^{4}$.

Quality of life is a term implying happiness and satisfaction with life and adequate functioning. It is a very broad term and conceptually quite complex; furthermore, it is a multidimensional concept. Health is one of the dimensions of quality of life, but it is not the only one; other dimensions have to do with financial aspects, interrelationships, sexuality, work, as well as cultural and spiritual aspects 5 .

The path of the HIV disease is characterized by episodes of acute exacerbation and long periods of relative health ${ }^{6}$. If the HIV disease advances, the result is diminished quality of life. Although quality of life is a multidimensional construction that does not accomplish universal agreement, some agreements have been reached regarding its relationship with ${ }^{7}$. The WHO defines it as the individual perception of the position towards life within the context of culture and value systems in which individuals live in relation to their goals, expectations, standards, and concerns ${ }^{4}$.

Quality of life is a particularly important measurement to determine the effects of the HIV-AIDS disease. Bearing in mind that this is a chronic disease and that the life expectancy of Human Immunodeficiency VirusInfected Individuals (PLWHA) is increasing because of developments in treatments and the dramatic change in mortality measurements, we do not expect deaths of individuals infected by this virus if treatment is appropiate $^{8}$. In spite of this, it has been reported that antiretroviral therapy (ARV) causes symptoms that affect, to a greater or lesser degree, PLWHA and impacts on their quality of life ${ }^{9}$.

\section{Objectives}

1. To measure the quality of life in a sample of individuals living with the AIDS virus in the city of Cali, Colombia.

2. Toidentify the relationship between global quality of life and its specific dimensions to some clinical and socio-demographic variables.

\section{METHODOLOGY}

Cross-section, observational, and descriptive study conducted between 2005 and 2006, with a non random 
sample of 137 patients with HIV-AIDS attending ambulatory services at three healthcare institutions in Cali. The patients were approached on the day of their medical or nursing consultation and those who accepted voluntary participation and had the availability of time to answer the survey were included. Among the inclusion criteria defined were: subjects over 18 years of age, with or without antiretroviral therapy, and with or without AIDS diagnosis at the time of the study.

The instruments used in measuring the variables included in the study have been broadly validated in different research projects and are of free distribution and use; these are: Demographic data questionnaire (age, gender, social security), Depression Scale from the Center for Epidemiological Studies [Escala de Depresión del Centro de Estudios Epidemiológicos $(C E S-D)]$, Revised Signs and Symptoms Checklist in people with HIV (SSC-HIVrev), HIV/AIDS-Targeted Quality of Life (HAT-QoL) instrument.

Depression Scale from the Center for Epidemiological Studies (CES-D). Measures symptoms of depression; it has 20 statements, responses range from 0 (never or rarely) to 3 (almost always or always). The total sum may range from 0 to 60 and a score of 16 or more indicates the need for a diagnostic evaluation for major depression. An estimated Alpha coefficient of 0.90 was obtained in a sample of 727 AIDS patients ${ }^{9}$.

Revised Signs and Symptoms Checklist in people with HIV (SSC-HIVrev). This is a 3-part checklist. Part I consists of 45 points and 11 factors, with confidence estimates ranging from 0.76 to 0.91 ; Part II consists of 19 symptoms related to HIV/AIDS, which are not grouped into factors but which can be of interest from the clinical perspective; and Part III has eight points related to gynecological symptoms. These eight points were subjected to principal components factor analysis with varimax rotation ( $\mathrm{N}=118 \mathrm{HIV}$ positive women), which yielded a solution of a factor that explained $71.8 \%$ of the variability; the confidence measurement of $0.94^{10}$.

HIVIAIDS-Targeted Quality of Life (HAT-QoL). This is a specific instrument to measure quality of life in Human Immunodeficiency Virus-Infected Individuals $(P L W H A)^{11}$. It has nine dimensions: «General Function» (which is a combination of the physical and social functions); «satisfaction with life»; «concerns about health»; «financial concerns»; «concerns about medications»; «concerns about their HIV condition»; «concerns about disclosing their diagnosis»; «confidence in the healthcare provider»; «sexual function». The total final evaluation was transformed into a linear scale from 0 to 100 , where 0 is the worst possible score and 100 is the best possible score.

The Project was approved by the Human Ethics Review Institutional Committee at Universidad del Valle. Prior to applying the data gathering instrument, the informed consent form was read explaining the objectives of the study and the conditions of free and voluntary participation. All the participants signed the informed consent form.

Data analysis. For the descriptive analysis of quantitative variables like quality of life and frequency of symptoms, the mean and standard deviation were calculated and percentages were calculated in categorical variables. The bivariate analy sis to determine differences in quality-of-life scores included the verification of the normality assumption with the Kolmogorov-Smirnov (K-S) test, the Student t test, and calculation of the Pearson correlation. The 95\% confidence interval (CI95\%) was calculated for measurement differences. The linear regression was used to determine the factors related with quality-of-life scores. The purpose with the construction of this model was more explicative than predictive, which is why no variable selection method was used. The global adjustment of the model was verified with the one-way ANOVA; the pertinence of each variable was verified via the statistical t test; fitting of the model was verified with the adjusted determination coefficient and the assumptions of residues were verified through the following manner:

1. Normality and zero means: with the K-S test, the QQ plot, and the residue histogram

2. Homoscedasticity: via residue plot versus predicted values.

3. No self-correlation: with the Durbin-Watson statistical package.

4. Multicollinearity: with the Variance Inflation Factor (VIF)

The results were analyzed via the SPSS version 13 statistical package.

\section{RESULTS}

The results were handled per instructions by the 
Table 1

Mean score of the dimensions in the scale for quality of life in persons with HIV/AIDS in Cali, Colombia

\begin{tabular}{lcc}
\hline \multicolumn{1}{c}{ Dimension } & Mean (0-100) & Standard deviation \\
\hline QUALITY OF LIFE & $\mathbf{5 8 . 8}$ & $\mathbf{1 7 . 8}$ \\
General function & 71.6 & 22.3 \\
Satisfaction with life & 74.2 & 21.0 \\
Concerns about health & 60.7 & 26.3 \\
Financial concerns & 41.3 & 31.5 \\
Attitude towards ARV medication & 72.4 & 23.6 \\
Feelings about being HIV+ & 62.9 & 33.6 \\
Concern about disclosing HIV condition & 49.2 & 28.6 \\
Confidence with healthcare personnel & 74.3 & 27.4 \\
Sexual function & 81.4 & 28.4 \\
\hline
\end{tabular}

*Direct scale, higher scores indicate better quality of life

authors. The population studied consisted of $96(71 \%)$ men, 37 (27\%) women, and 4 (3\%) transgender; $88 \%$ of the subjects reported having some type of healthinsurance, most $(57.3 \%)$ belonged to the subsidized healthcare regime of the Health and Social Security System. Twenty-seven percent had been diagnosed with AIDS and $64 \%$ were receiving antiretroviral therapy at the time of the study. Regarding age, the mean was $35.3 \pm$ 10.2 years with a range from $20-73$ years, $9 \%$ were above 50 years of age. The day of the interview, the participants reported an average of $17 \pm 11$ symptoms, the data of the characteristics of the sample are published in depth in another article by Valencia et al. ${ }^{1}$

Quality of life. The average global quality-of-life score in the sample of patients was $59 \pm 17.8$ points in a standardized scale from $0-100$. Table 1 shows the score for each of the nine quality-of-life dimensions. Note that the lowest scores in the dimensions correspond to financial concerns (41.3) and to the difficulty of disclosing their HIV condition (49.2). The dimensions revealing the best scores are sexual function (81.4), satisfaction with life (74.2), and satisfaction with attention received from healthcare personnel (74.3).

The bivariate analysis per healthcare regime (type of insurance) revealed that individuals in the contributive regime had a better global score on the quality-of-life scale compared to the global score of individuals with subsidized regime (average: 66.21 vs. 53.8, respectively; $\mathrm{p}=0.00$ ). These statistically significant differences are also observed in the scores for the following dimensions: «general function», «concerns about health», «financial concerns», and «concerns about their HIV condition» (Table 2). Regarding sex, statistically significant differences were only found in the dimension on concerns about health, which is lowest for the female group (52.8 vs. $63.5 ; \mathrm{p}=0.032$ ).

Upon analyzing quality of life according to age, statistically significant difference was only found in the dimension for «confidence with the attention offered by the healthcare provider»; this being the highest qualityof-life score for those over 50 years of age (93 vs. 72.4; $\mathrm{p}=0.0120$ ).

No statistically significant differences were observed between individuals with or without children under their care. Regarding the relationship between quality of life and treatment or not with antiretroviral medication therapy (ARV), it was found that quality of life is generally better for those taking the medications than for those who were not taking them ( $66 v s .46 ; \mathrm{p}=0.00$ ). Analyzing the relationship between ARVT and the different dimensions of the scale, significant differences were noted in the dimensions dealing with «financial concerns and concerns about disclosing their HIV+ condition» (47.6 vs. 30; $\mathrm{p}=0.001$ and 70.1 vs. 49.7; $\mathrm{p}=0.000$, respectively). To explore the relationship between symptoms and quality of life, we measured the 
Table 2

Relationship between quality of life with socio-demographic and clinical variables in Human Immunodeficiency Virus-Infected Individuals (PLWHA), Cali

\begin{tabular}{lllll}
\hline \multicolumn{1}{c}{ Factor $^{1}$} & Category & Total & Mean \pm SD $^{2}$ & Cl95\% $^{3}$ \\
\hline Type of healthcare regime & Subsidized & 78 & $54.0 \pm 17.6$ & $6.3-18.2$ \\
& Contributive & 58 & $66.2 \pm 15.8$ & \\
ARV Treatment & Yes & 87 & $66.6 \pm 15.7$ & $16.1-26.8$ \\
& No & 49 & $46.0 \pm 13.3$ & \\
Symptoms of Depression & Yes & 7 & $42.3 \pm 12.1$ & $4.4-31.6$ \\
& No & 129 & $60.1 \pm 17.7$ & \\
Gender & Female & 37 & $57.2 \pm 15.8$ & \\
& Male & 95 & $60.2 \pm 18.9$ & $6.2-18.3$ \\
Emotional or physical abuse & Yes & 54 & $52.0 \pm 16.2$ & $7.7-23.6$ \\
& No & 82 & $64.0 \pm 17.3$ & \\
Sexual abuse & Yes & 22 & $46.3 \pm 14.8$ & \\
& No & 114 & $61.7 \pm 17.3$ & \\
\hline
\end{tabular}

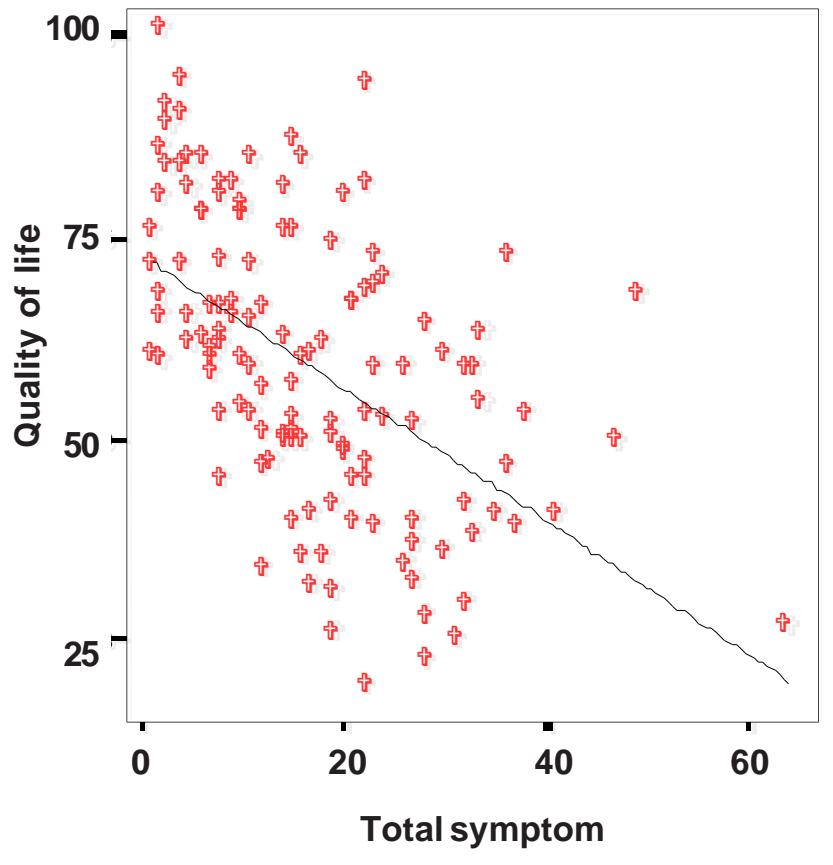

Correlation $($ Pearson $r)=-0.525$ Significance $(p<0.01)$

Figure 1. Correlation between quality of life and symptoms in PLWHA relationship with the average frequency of symptoms, the intensity of the symptoms, and the symptoms of depression. The score for quality of life was lower among those with symptoms of depression - both in the global score (63.9 vs. 51.97; $\mathrm{p}=0.000)$ and in the dimensions of general function $(\mathrm{p}=0.000)$, concerns about health $(\mathrm{p}=0.02)$, concerns about their HIV condition, concerns about ARV medications ( $\mathrm{p}=0.008$ ), and sexual function ( $\mathrm{p}$ : 0.005). The Pearson correlation between quality of life and frequency of symptoms revealed that as symptoms increase the quality of life is impaired (r: -0.525 p<0.05) (Figure 1).

Multivariate analysis. To determine factors related to quality of life and its nine dimensions, we used a multiple linear regression for global quality of life and nine models separated for each of the dimensions. Eight of the nine variables included in the model for quality of life explain $53 \%$ of the variability in quality-of-life scores; however, it was found that only the frequency of symptoms and the use of ARV therapy are significant to explain quality of life $(\mathrm{p}<0.01)$. The negative coefficient $(-.340, t=-4.962, \mathrm{p}=0.000)$, for the first variable, indicates that the number of symptoms increase in an individual with HIV, global quality of life diminishes; the positive coefficient (.437, $\mathrm{t}=6.335, \mathrm{p}=0.000)$, for the second 
Table 3

Factors related to quality of life and two specific dimensions of quality of life

\begin{tabular}{|c|c|c|c|}
\hline \multirow[b]{2}{*}{ Variables } & \multicolumn{3}{|c|}{ Multiple regression model for Quality of Life and Dimensions* } \\
\hline & Standardized beta coefficient & $\mathbf{R}^{2}$ & $\mathbf{p}$ \\
\hline Global Quality of Life & & & 0.000 \\
\hline Constant & & 0.532 & 0.000 \\
\hline Frequency of symptoms & -.340 & & 0.000 \\
\hline Depression & -.110 & & 0.108 \\
\hline Type of regime & -.058 & & 0.409 \\
\hline ARV treatment & .437 & & 0.000 \\
\hline Abuse & -.091 & & 0.344 \\
\hline Physical abuse & .015 & & 0.876 \\
\hline Sexual abuse & -.106 & & 0.135 \\
\hline Sex & -.039 & & 0.554 \\
\hline Satisfaction with life & & & 0.001 \\
\hline Constant & & 0.318 & 0.000 \\
\hline Frequency of symptoms & -.409 & & 0.001 \\
\hline Depression & -.212 & & 0.046 \\
\hline Abuse & -.003 & & 0.982 \\
\hline Physical abuse & .121 & & 0.407 \\
\hline Sexual abuse & -.287 & & 0.008 \\
\hline Over 50 years of age & -.336 & & 0.003 \\
\hline Worry about medications & & & 0.005 \\
\hline Constant & & 0.450 & 0.002 \\
\hline Frequency of symptoms & -.438 & & 0.008 \\
\hline Depression & -.148 & & 0.316 \\
\hline ARV treatment & .260 & & 0.044 \\
\hline Abuse & -.493 & & 0.031 \\
\hline Physical abuse & .213 & & 0.348 \\
\hline
\end{tabular}

* The models with the others dimensions were omitted because they did not provide optimum prediction

variable, indicates that individuals who received ARV therapy have better quality of life than those who did not receive it. The model fulfills all the statistical suppositions; no multicollinearity problems were found, and the variance was homoscedastic and the distribution of residues was normal.

Table 3 shows the regression models for the dimensions with the greatest number of independent variables. It is noted that the amount of symptoms (frequency of symptoms) negatively affects the following dimensions: general function, satisfaction with life, concerns about health, and concerns about medications. For the dimension on concern about being HIV+, the bivariate or multivariate analyses did not reveal variables to explain that dimension.

Increased frequency of symptoms, the presence of depression, sexual abuse, and being over 50 years of age negatively affect the dimension of «satisfaction with life». These variables explain $31.8 \%$ of the variance for this dimension. In the dimension on concern about ARV medications, it is noted that taking them improves the quality of life in said dimension by $26 \%$, and along with 
the physical abuse and frequency of symptoms variables help to explain $45 \%$ of the variability in that dimension.

Individuals over 50 years of age $(\mathrm{p}=0.021)$ who are in the contributive healthcare regime $(\mathrm{p}=0.003)$, have greater scores in the dimension of «confidence with the healthcare provider»; both variables -along with the constant- explain $21.1 \%$ of the global variability of that dimension. In other dimensions, it is noted that quality of life is affected by symptoms of depression and by being or not being affiliated to healthcare insurance; the dimension on «financial concerns» is negatively affected in individuals with subsidized-type healthcare regime; the sexual function dimension is most affected in individuals suffering from depression $(\mathrm{p}=0.016)$.

\section{DISCUSSION}

The results in this study agree with reports from other studies; diverse factors like the symptoms perceived by PLWHA have been associated to lower quality-oflife scores ${ }^{12}$; likewise, some social characteristics have been associated with a low quality-of-life index ${ }^{13}$. In contrast, factors like middle or high economic level in terms of income and not having children under their care have been associated to better quality of $\operatorname{life}^{14}$. In general terms, it is observed that the global variability explained by the variables in each of the dimensions is quite high compared to results obtained by Phaladze K et $a .^{7}$

In this study, the patients with the highest quality-oflife scores had better access to healthcare services. Those affiliated to a contributive healthcare regime had better-quality services; presenting fewer financial concerns, fewer symptoms of depression, received antiretroviral therapy, and experienced lower frequencies and intensities of symptoms; they also evidenced fewer antecedents of sexual or physical abuse. These findings are similar to those reported by Phaladze et al. ${ }^{7}$ who found a close correlation between intensity of symptoms and low quality of life, at the expense of patients' functional capacity impairment. Our results, like others, show that high frequency and intensity of symptoms have negative effects on quality of life $\mathrm{e}^{15,16}$ and on satisfaction for life; additionally, increased states of depression impairs quality of life.

Several studies ${ }^{13,17,18}$ have identified an inversely proportional relationship between quality of life and poverty, as suggested by the results in this study. Hence, the socioeconomic conditions determine greater vulnerability in acquiring the infection, as well as in living with a better quality of life. This phenomenon denotes the continuity of the chain of social factors characterizing this disease, turning it into a vicious circle: lower income is consequential of lack of work and, thus, less access to healthcare services. This situation also diminishes possibilities for access to antiretroviral therapy and to integral healthcare services, which contributes to worsening of psychological and physical conditions of individuals affected by AIDS and their families. The results confirm statements made by other authors in that the quality of life of individuals with HIV/AIDS is a complex constellation of disease, poverty, stigma, discrimination, and lack of treatment.

This study did not reveal a statistically significant association between quality of life and gender. A significant relationship was only identified in one of the dimensions in the quality-of-life scale, concerns about health and gender, showing that women have a lower quality of life with respect to concerns generated by their health condition. Relationships with the adherence variable are not presented in this article.

\section{CONCLUSION}

Frequency of signs and symptoms and taking ARV medications were the variables most associated to quality of life in inverse relationship for the first, i.e., a greater number of signs and symptoms indicate lower quality of life; and in direct association, for the latter, meaning better quality of life among those receiving medications. These aspects correlate with the natural history of the disease, which has shown that the benefits of antiretroviral therapy in terms of the prognosis are greater than the adverse effects noted specifically at the beginning of therapy.

These findings agree with those reported by other authors like $\mathrm{Wu}^{12}$. Improving the immune system and diminishing viremia translates to lesser symptoms, lowered options of developing opportunistic infections, and greater chances of reinsertion into the social environment and the labor market. These factors are undoubtedly reflected in the different dimensions measuring quality of life. Figure 2 presents the scheme of the variables 


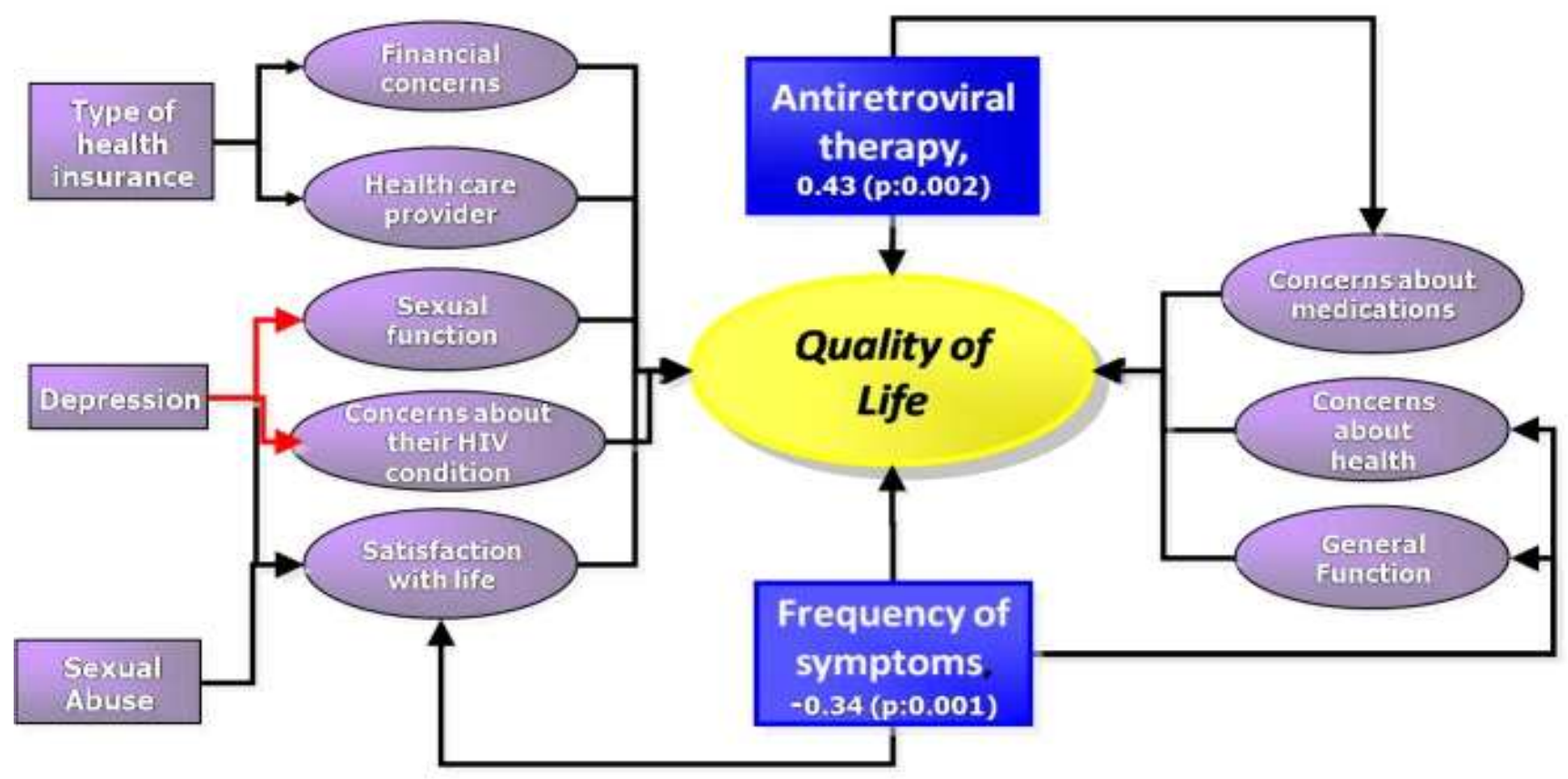

\section{$\longrightarrow$ Dimensions HAT-QoL's Instrument Independent variables}

Figure 2. Graphic representation of the relationship among some variables and quality of life (global and per dimension) in individuals living with the AIDS virus in some healthcare institutions in Cali, Colombia

related to global quality of life and with their dimensions in individuals living with the AIDS virus.

Implications for practice and research . The HIV/ AIDS disease is a public health issue, given the dimensions of its propagation. Given that it is a chronic disease, this study suggests several challenges and questions to address from different disciplines, especially from the field of nursing: How to improve in society and in nursing care the quality of life of individuals living with the AIDS virus?

- Health professionals and society in general can adopt positive attitudes and educate their patients to live better with HIV/AIDS.

- Healthcare services must adequately and continuously provide medications to their users so they can keep their illness under control.

- Nursing can teach and support strategies to reduce functional limitations such as nutrition and exercise.

- Nursing can provide support and education for selfcare and family care that contribute to diminishing the frequency and intensity of the symptoms.
- Maintaining a good quality of life requires healthcare with a holistic and integral focus, given the different dimensions that define it.

Limitations. This study was conducted on a non random sample of patients among those attending health ambulatory medical and nursing control services in three healthcare institutions in the city of Cali. The results can be extrapolated to patients with similar characteristics, which is why we recommend further studies with random samples of patients.

Conflict of interest. None of the authors has conflicts of interest related to this study.

\section{ACKNOWLEDGMENTS}

This study was funded by the Colombian Institute for the Development of Science and Technology (COLCIENCIAS) through contract No 11060416327 and by the School of Nursing at Universidad del Valle in Cali, Colombia. 


\section{REFERENCES}

1. Valencia CP, Canaval GE, Rizo V, Correa D, Marín D. Signos y síntomas en personas que viven con el virus del SIDA. Colomb Med. 2007; 38: 365-74.

2. Nicholas PK, Kemppainen JK, Canaval GE, Corless IB, Sefcik $\mathrm{EF}$, Nokes KM, et al. Symptom management and self-care for peripheral neuropathy in HIV/AIDS. AIDS Care. 2007; 19: 179-89.

3. Nicholas P, Voss J, Corless I, Lindgren T, Wantland D, Kemppainen J, Canaval GE, et al. Unhealthy behaviors for selfmanagement of HIV-related peripheral neuropathy. AIDS Care. 2007; 19: 1266-73.

4. Centers for Disease Control and Prevention (CDC). Measuring healthy days. Population assessment of health-related quality of life. Atlanta: CDC; 2000.

5. Ferrans CE. Quality of life: Conceptual issues. Semin Oncol Nurs. 1990; 6: 248-54.

6. Nokes MK, Coleman C, Hamilton MJ, Corless IB, Selcik E, Kirsey K, et al. Health-related quality of life in persons younger and older than 50, who are living with HIV/AIDS. Res Aging. 2000; 22: 290-310.

7. Phaladze NA, Human S, Dlamini SB, Hulela EB, Hadebe IM, Sukati NA, et al. Quality of life and the concept of living well with HIV/AIDS in sub-Saharan Africa. J Nurs Schol. 2005; 37 : 120-6.

8. Palella FJJr, Delaney KM, Moorman AC, Loveless MO, Fuhrer J, Satten GA, et al. Declining morbidity and mortality among patients with advanced human immunodeficiency virus infection. HIV Outpatient Study Investigators. New Engl J Med. 1998; 338: 853-60.

9. Holzemer WL, Henry SB, Nokes KM, Corless IG, Brown M, Powell Cope GM, et al. Validation of the sign \& symptom check list for persons with HIV disease (SSC-HIV). JAdv Nurs. 1999; 3: 104149.
10. Holzemer WL, Hudson A, Kirskey K, Hamilton MJ, Bakken $\mathrm{S}$. The revised sign and symptom check list for HIV (SSC-HIV rev). J Assoc Nurs AIDS Care. 2001, 12: 60 -70.

11. Holmes WC, Shea JA. A new HIV/AIDS-targeted quality of life (HAT- QoL) instrument: development, reliability, and validity. Med Care. 1998; 36: 138-54.

12. Wu AW, Dave NB, Diener-West M, Sorensen S, Huang, IC, Revicki DA. Measuring validity of self-reported symptoms among people with HIV. AIDS Care. 2004; 16: 876-81.

13. Lorenz KA, Shapiro MF, Asch SM, Bozzette SA, Hays RD. Associations of symptoms and health-related quality of life: findings from a national study of persons with HIV infection. Ann Int Med. 2001; 134: 854-60.

14. Préau M, Leport C, Salmon-Ceron D, Carrieri P, Portier H, Chene G, et al. Health-related quality of life and patientprovider relationships in HIV-infected patients during the first three years after starting PI-containing antiretroviral treatment. AIDS Care. 2004; 16: 649-61.

15. Bing EG, Hays RD, Jacobson LP, Chen B, Gange SJ, Kass NE, et al. Health-related quality of life among people with HIV disease: Results from the multicenter AIDS cohort study. Qual Life Res. 2000; 9: 55-63.

16. Call SA, Klapow JC, Stewart KE, Westfall AO, Mallinger AP, DeMAsi RA, et al. Health-related quality of life and virologic outcomes in an HIV clinic. Qual Life Res. 2000; 9: 977-85.

17. Hays RD, Cunningham WE, Sherbourne, CD, Wilson IB, Wu AW, Cleary PD, et al. Health-related quality of life in patients with human immunodeficiency virus infection in the United States: results from the HIV cost and services utilization study. Am J Med. 2000; 108: 714-22.

18. Sousa KH, Holzemer WL, Henry SB, Slaugther R. Dimensions of health-related quality of life in persons living with HIV disease. J Adv Nurs. 1999; 29: 178-87. 